\title{
The Formulation of One Tambon One Product Concept as the Effort to Empower Micro, Small \& Medium Enterprises in Designing the Strategy to Improve Their Competitive Advantage and Market Access in Welcoming ASEAN Market in Great Malang
}

Gunarianto

University of Widyagama, Faculty of Economics, Malang-Indonesia

\section{Address For Correspondence:}

Gunarianto, Faculty of Economic, University of Widya Gama Malang, Jl. Borobudur No.35, Blimbing, Malang City, East Java, 65141, Indonesia.

\section{A RT ICLE INFO}

Article history:

Received 12 October 2017

Accepted 22 December 2017

Available online 31 December 2017

Keywords:

One Tambon One Product, MSME SWOT

\begin{abstract}
A B S T R A C T
Competitive advantage and market access have a good impact on Micro, Small \& Medium Enterprises (MSME) in achieving their economical outputs such as economical growth, job creation, and poverty reduction Gunarianto, et al (2008). Two long-term objectives are proposed for this research. First is to ensure that every local MSME has comprehensively understood One Tambon One Product concept, which it is proved by the ability of local MSME in deciding whether the concept shall be applied or not, and if yes, also in making strategic plan for implementing the concept. Secondly is to identify factors supporting and constraining the successful application of One Tambon One Product concept at local MSME. The object of research is MSME in Great Malang. These MSME are selected with some approaches, including making a long list of leading commodities, determining one leading commodity as priority, determining the application of One Tambon One Product concept at local MSME, and making a plan of action (a road map). Research has given some results. The leading sector in Malang City includes: (a) Sector of Water Supply, Trash \& Waste Management, and Recycle; (b) Sector of Construction; (c) Sector of Wholesale \& Retail Trading of Car \& Motorcycle and Reparation; (d) Sector of Education Service; and (e) Sector of Health and Social Activity Services. The leading sector in Batu City is consisting of: (a) Sector of Water Supply, Trash \& Waste Management, and Recycle; (b) Sector of Construction; (c) Sector of Wholesale \& Retail Trading of Car \& Motorcycle and Reparation; (d) Sector of Accommodation and Food \& Beverage Provisioning; and (e) Sector of Other Services. The leading sector in Malang Regency is represented by: (a) Sector of Agriculture, Forestry and Fishery; (b) Sector of Processing Industry; (c) Sector of Water Supply, Trash \& Waste Management, and Recycle; and (d) Sector of Construction. Based on the result of SWOT analysis, development strategy for MSME in Great Malang remains in the cluster of SO Strategy. Conclusion this reseach that this strategy cluster shall be the priority of local governments in Great Malang. The implication from this result is that given a fact the economic of Great Malang has changed and also been shifting from the sectors orienting on agriculture to the sectors emphasizing on industry, trade and service, then the governments in Great Malang shall consider the last three sectors when planning to conduct local development.
\end{abstract}

\section{INTRODUCTION}

Micro, Small \& Medium Enterprises (MSME) in Great Malang have been developing naturally based on their distinctive characteristic without intervention from local government. For instance, Leather Handicrafts MSME are very popular in Malang Regency while Tempe Chips MSME are greatly dominant in Malang City.

Open Access Journal

Published BY AENSI Publication

(C) 2017 AENSI Publisher All rights reserved

This work is licensed under the Creative Commons Attribution International License (CC BY). http://creativecommons.org/licenses/by/4.0/

To Cite This Article: Gunarianto, The Formulation of One Tambon One Product Concept as the Effort to Empower Micro, Small \& Medium Enterprises in Designing the Strategy to Improve Their Competitive Advantage and Market Access in Welcoming ASEAN Market in Great Malang. Aust. J. Basic \& Appl. Sci., 11(15):34-46, 2017 
Meanwhile, Processed Cassava MSME represents the very existence of Batu City. The development of MSME in Great Malang is not different from MSME in other regions. Most of them are not professionally managed, have low competitive advantage, lack of sound management, and concern only with fulfilling household necessity. Mulyono (2016) found that Micro, Small \& Medium Enterprises (MSME) would develop in advance if they are profesionally managed, have competitive advantage, and receives the needed support from local government. There are 1,209 MSME spread throughout three regions of Great Malang, and the distribution of MSME in Great Malang is shown in the following table.

Table 1: The Distribution of MSME in Great Malang

\begin{tabular}{|c|c|c|}
\hline No. & City / Regency & MSME \\
\hline 1. & Malang City & 816 \\
\hline 2. & Malang Regency & 96 \\
\hline 3. & Batu City & 117 \\
\hline & Total & 1,029 \\
\hline
\end{tabular}

Source: MSME Directory, Department of Industry and Trade for East Java Province, 2016

The objective of this research is: (1) to ensure that every local MSME has comprehensively understood One Tambon One Product concept, which it can be proved with the ability of local MSME in deciding whether this concept is applicable or not, and if yes, also verified with their ability in making strategic plan for implementing the concept; (2) to identify factors supporting and constraining successful application of One Tambon One Product concept at local MSME; and (3) to formulate One Tambon One Product concept applicable to local MSME.

Theme of this research is to support the achievement of Research Strategic Plan (Research Prime Plan) prepared by the Faculty of Economic, Malang Widyagama University. The subject matter discussed in this research is MSME Empowerment in Welcoming ASEAN Market.

This research is a comprehensive follow-up from previous studies conducted by other research team preceding the author. Themes of MSME, poverty alleviation, and competitive advantage have been discussed previously by Tuti Hastuti et al., (2007), Tuti Hastuti et al., (2008), Gunarianto et al., (2008), Gunarianto \& Nasri (2011), Tuti Hastuti et al., (2013, 2014) and also Mulyono (2015, 2016). As said by Tuti Hastuti et al., (2007), the dominant factors that cause poverty in many regions are economic, structure, situation, politic and society. Regency/City Governments bestow many grant-in-aids to the poor and have done programs and activities to support these grants. Such grants are given in many forms such as: cash direct grant, indirect grant, physical structures-infrastructures grant, public service grant, stimulant grant, empowerment grant, nine basic necessities grant, and livestock grant. Business activity done by MSME at regency/city levels does not give significant contribution to people economic. This problem is dominantly caused by factors of non-supportive culture and weak human resource. Moreover, Tuti Hastuti et al., (2008) declared, supported by Mulyono (2015), that poverty can only be alleviated through education, health, and economic services provided by the empowered MSME. The empowerment of MSME can be done by increasing community participation into MSME activity. Meanwhile, Gunarianto et al., (2008) explained that policies and programs released by the governments for poverty mitigation are not yet effective to solve poverty problem and also remain incapable to stop the circle and the legacy of poverty. Reasons behind this matter are that the policy is often sector-oriented and centralized which perceives poverty as governmental issue (centralistic agenda); the multi-party collaboration is lacking; and the poverty eradication program is not sustainable. Mulyono (2016) asserted that MSME and its empowerment so far have not been the priority of the government to improve people economic.

\section{Review of literatures:}

Local Competitive Advantage:

MSME competitive advantage shall be a very important thing to consider. As noted by Michael E. Porter (1980), the competitive advantage of a nation is determined by several factors, such as: natural resource, market demand, company strategy, and rivality within company and across companies. It is also said that the cluster of domestic rivals across the participants of similar economic activity would lead to a sustainable innovation, and it helps increasing the level of competitive advantage of the participants in the cluster.

Law No.23/2014 on Local Government has required local government to improve local self-sufficiency through the efficient and optimum use of natural resource to increase local competitive advantage by giving attention to local potentials and characteristics. One Tambon One Product (OTOP) concept applied by local MSME is a dynamic concept consisting of positive and competitive characteristics, such as: resource potential, human resource availability, product uniqueness, market absorption capacity, and MSME cluster existence.

In other words, in term of these characteristics, the benefits of OTOP concept to MSME can be described as follows:

(1) OTOP concept is very concern with the improvement of products, either goods or services, delivered by MSME. 
(2) The value chain of each MSME and its cluster is always integrated and keeping them as a system.

(3) The competence of MSME is referred to resource uniqueness and its capability to create competitive advantage.

(4) OTOP helps MSME to gain better market opportunities.

According to G. Hamel \& CK. Prahalad (1993), if companies want to overcome their competitors in the future, they must have strong orientation to grab up opportunities, including market share. Prahalad defines One Tambon One Product as a set of skills and technologies that allow an organization or company to provide benefits to customers. In other words, One Tambon One Product would be a set of resources and capabilities owned by organization, either in the form of tangible assets or intangible assets. This concept is identical with One Village One Product, a concept developed by Hiramatsu for Oita District in Japan, or SAKASAKTI (Satu Kota Satu Keunggulan Produk), as concept suggested by Martani Huseini (2000). Thus, the author declares that the competitive advantage of local MSME can be improved then by applying One Tambon One Product.

\section{MSME Development with One Tambon One Product:}

One Tambon One Product (OTOP) is firstly introduced by Hamel \& Prahalad (1994). They suggest that One Tambon One Product is a set of skills and technologies integrated and accumulated from a learning process in organization (business setting) which then gives organization a higher competitive advantage. It can be said that OTOP is organizational learning because it helps organization to know how to coordinate many production factors and to understand how to integrate various technologies. OTOP also guides organization into how to harmonize technologies of work and also how to generate value for customers. It is also deduced that OTOP is a deep comitment to work across the boundaries of organization. As said by Gallon, Stilman \& Coates, "One Tambon One Product is the things that some companies or regions know how to do uniquely well and also that have the scope to provide them with a better-than average degree of success over the long term".

In regional economic perspective, One Tambon One Product represents a competence of a certain region to create physical and non-physical infrastructures to attract domestic and foreign investors. Experts insist to relate One Tambon One Product (core competence) with various terms such as resources, strengths, skills, capabilities, organizational knowledge, distinctive competence, and intangible assets. Barney (1995) admitted that resources and capabilities are important to cope with competition, and both must have attributes of (1) valuable, (2) rare, and (3) inimitable. Prahalad \& Hamel (1994) proposed three parameters needed to identify core competence in organization: (1) whether core competence gives organization a potential access to many markets; (2) whether it makes organization to give a meaningful contribution to customers; and (3) whether it keeps the competitors from imitating organization product. According to Riana (2007), One Tambon One Product is a base for sustainable competitive advantage, and to have One Tambon One Product as its core competence, some criteria must be met, such as: (1) core competence is activities or processes that underly value of goods or services; (2) it helps organization to have better performance than competitors; and (3) it shall be difficult for competitors to imitate.

By the presence of OTOP concept, the local MSME is required give a strong attention to a product that has been made at low-cost production based on resources and competences, either gifted or learned. The process is illustrated in the following:

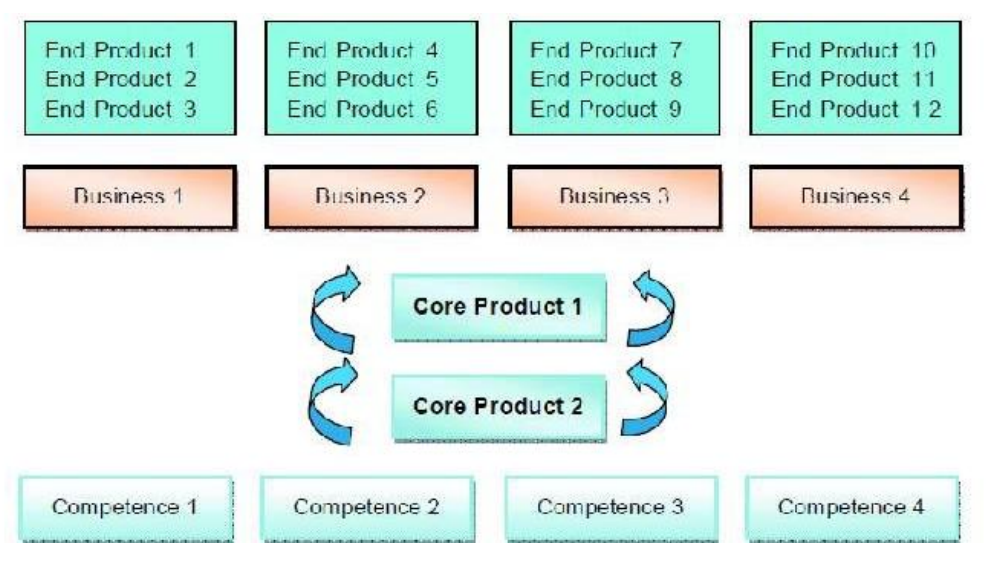

Fig. 1: OTOP Concept

\section{Previous Research:}

Gunarianto \& Nasri (2011) examined core competence of local industries in Pasuruan City and found that MSME competitive advantage is the accumulation of capabilities and cooperations that MSME organization 
have developed to create product with the expected quality. However, this development frame would be meaningless if it is used only as a political decision, and therefore, it needs implementation involving support of all stakeholders, including local government, Local House of Representatives, related departments, business participants, cooperatives and associations, and colleges.

Furthermore, Tuti Hastuti et al., (2013) investigated the empowerment of MSME in Great Malang and discovered that the proper solution for problems challenging MSME in Great Malang is by inviting MSME into sessions of consult and training, and also enlisting supports from relevant patrons for MSME empowerment. Five development programs are suggested to generate MSME progress, such as: (i) Human Resource Development Program; (ii) MSME Development Program; (iii) Self-Supported Capitalization Program; (iv) Business Development Program; and (v) Effective Information Supply Program.

MSME Empowerment Team of PERFORM conducted a study on similar theme but on different object from June to August 2002. It did observation on several regions. This observation gave some results: (1) There is a gap between concept and application; (2) Program initiative is lacking; (3) Strategies for local economic development are greatly dependent on external investment, or only waiting for it; (4) Relationship between local government and business world is not effective due to a sense of prejudice among them; (5) The approach to concept implementation is still narrow-minded because it is only focused on supply and production grants (technical aid, equipment grant, credit, etc); (6) Marketing aspect and the importance of recognizing buyers' demand or taste are neglected. The participation of economic agents and stakeholders must thus be extensified by developing a cluster chain to accommodate their presence LED Team (2012).

\section{Method of research:}

\section{Research Approach:}

The formulation of One Tambon One Product concept to be applied at local MSME involves some stages of analysis. The following figure describes the analytical frame consisting of several stages in formulating One Tambon One Product for local MSME. The output of this analysis is the action plan (the road map) in formulating One Tambon One Product concept for local MSME.

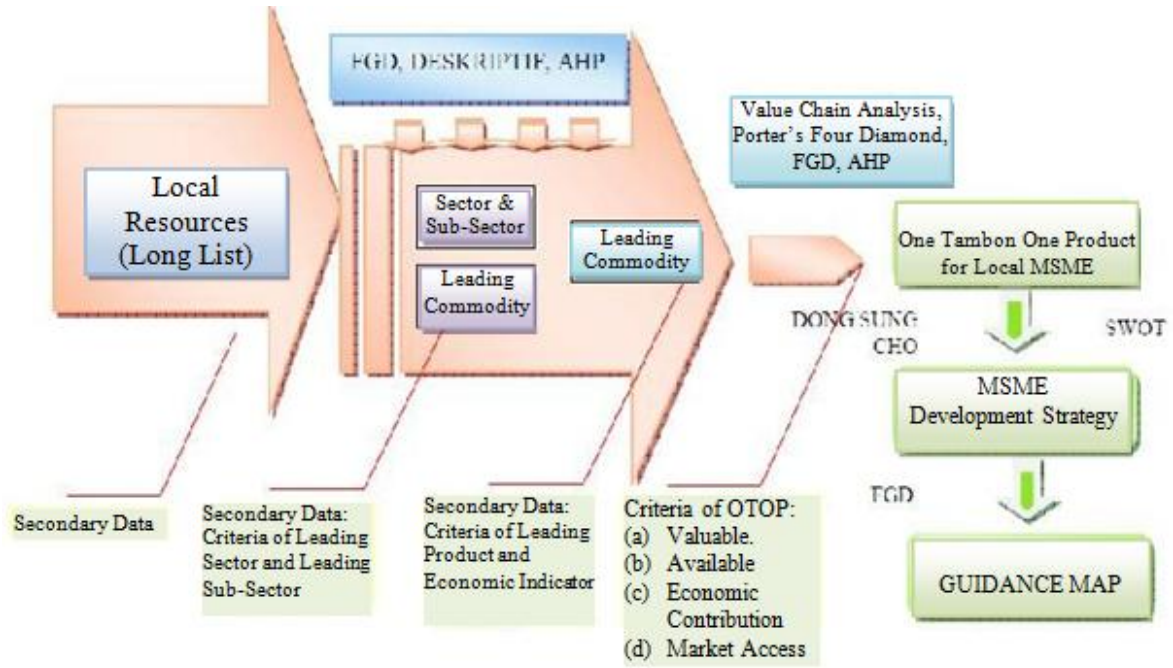

Fig. 2: The Analytical Frame of OTOP Formulation for MSME

\section{Location, Population, and Sample of Research:}

The location of research is Malang City, Batu City and Malang Regency. Population is Micro, Small \& Medium Enterprises (MSME). Research sample is MSME that applies One Tambon One Product (OTOP). Sample is determined by cluster sampling with some criteria, such as:

1. MSME are located in same business centers and have same business.

2. MSME in the cluster have strength, endurance, supporting capacity, and competitive advantage at greater level over other economic powers.

\section{Data Collection Method and Research Subject:}

\section{Field Survey:}

It is done to explore deeper data on One Tambon One Product formulation strategy and also to get information about the program to improve MSME competitive advantage in Great Malang. 


\section{Participatory Research Appraisal (PRA):}

PRA is a qualitative method to collect the data. MSME as research subjects are exposed to appraisal process. In here, the subjects are required to identify factors of strengths, weakness, opportunities, and threats that they often face.

3. Focus Group Discussion (FGD)

FGD gathers the participants into a discussion facilitated by moderator. Participants reveal their problems and their need for solution. FGD participants may include experts or academicians on economic field, bureaucrats, NGO, community, college, Local House of Representatives, journalists, and business agents.

4. Seminar \& Workshop

Seminar is held to discuss temporary findings on the formulation of One Tambon One Product for local MSME, and the result is published and presented at the workshop to increase the perfection of OTOP concept.

\section{Data Analysis Method:}

This research operates survey method on MSME in each local predetermined. Data of MSME quantity and quality are obtained from Department of Industry, Trade \& Cooperative in research location. Primary data are collected after soliciting the completed questionnaire from MSME.

\section{Result of research:}

Great Malang or also called as Malang Metropolitant Region is the composite of three regions in East Java, respectively Malang City, Batu City and Malang Regency. Great Malang Region is the second biggest metropolitan region in East Java after Germakertosusila Plus with Surabaya City as the center. All regions in Great Malang are the part of Malang Administrative Unit which during colonial age, it includes some regions outside Malang, such as Lumajang, Pasuruan and Probolinggo (Article 19, Verse 3, Local Regulation of East Java Province, No.5/2012 on Space Order Plan for Province Region for 2011-2031).

\section{Analysis on Leading Sector:}

Analysis on Leading Sector in Malang City:

Table 2: SLQ and DLQ of Malang City in 2012-2016

\begin{tabular}{|c|c|c|c|c|c|c|}
\hline Sector & Description & $\begin{array}{c}\text { SLQ } \\
\text { Means }\end{array}$ & Remark & $\begin{array}{c}\text { DLQ } \\
\text { Means }\end{array}$ & Remark & Conclusion \\
\hline $\mathrm{A}$ & Agriculture, Forestry and Fishery & 0.0216 & $<1$ & 0.9808 & $<1$ & Laggard \\
\hline $\mathrm{B}$ & Mining and Excavation & 0.0199 & $<1$ & 0.9046 & $<1$ & Laggard \\
\hline $\mathrm{C}$ & Processing Industry & 0.8630 & $<1$ & 0.9660 & $<1$ & Laggard \\
\hline $\mathrm{D}$ & Electric and Gas Supplies & 0.1143 & $<1$ & 1.0133 & $>1$ & Reliable \\
\hline $\mathrm{E}$ & $\begin{array}{c}\text { Water Supply, Trash \& Waste Management, } \\
\text { and Recycle }\end{array}$ & 2.1057 & $>1$ & 1.0125 & $>1$ & Excellent \\
\hline $\mathrm{F}$ & Construction & 1.3570 & $>1$ & 1.0173 & $>1$ & Excellent \\
\hline G & $\begin{array}{c}\text { Wholesale \& Retail Trading of Car \& } \\
\text { Motorcycle and Reparation }\end{array}$ & 1.6883 & $>1$ & 1.0068 & $>1$ & Excellent \\
\hline $\mathrm{H}$ & Transporation and Warehousing & 0.8547 & $<1$ & 1.0033 & $>1$ & Reliable \\
\hline $\mathrm{I}$ & $\begin{array}{l}\text { Accommodation and Food \& Beverage } \\
\text { Provisioning }\end{array}$ & 0.8574 & $<1$ & 1.0088 & $>1$ & Reliable \\
\hline $\mathrm{J}$ & Information and Communication & 0.8472 & $<1$ & 1.0126 & $>1$ & Reliable \\
\hline $\mathrm{K}$ & Finance and Insurance Services & 1.0257 & $>1$ & 0.9995 & $<1$ & Prospective \\
\hline $\mathrm{L}$ & Real Estate & 0.8550 & $<1$ & 1.0116 & $>1$ & Reliable \\
\hline $\mathrm{M}, \mathrm{N}$ & Company Service & 0.9401 & $<1$ & 1.0120 & $>1$ & Reliable \\
\hline $\mathrm{O}$ & $\begin{array}{c}\text { Government Administration, defense and } \\
\text { Mandatory Social Service }\end{array}$ & 0.6612 & $<1$ & 0.9869 & $<1$ & Laggard \\
\hline $\mathrm{P}$ & Education Service & 2.8376 & $>1$ & 1.0144 & $>1$ & Excellent \\
\hline $\mathrm{Q}$ & Health and Social Activity Services & 3.7897 & $>1$ & 1.0192 & $>1$ & Excellent \\
\hline $\mathrm{R}, \mathrm{S}, \mathrm{T}, \mathrm{U}$ & Other Services & 2.1918 & $>1$ & 0.9918 & $<1$ & Prospective \\
\hline
\end{tabular}

Source: Data are processed.

Based on SLQ and DLQ means scores in table above, the leading sectors in Malang City can be described as following:

\section{Water Supply, Trash \& Waste Management, and Recycle:}

This sector covers many economic activities related with water, such as collecting, processing, and distributing water through pipelines for household and industrial necessities. Also, waters from river, lake, spring, rain and others are retained, refined and processed for agriculture. This sector contributes to Malang City economic for 0.19 percents in 2016. Growth rate of this sector is 4.92 percents which is greater than 3.71 percents in 2015 . 


\section{Construction:}

In 2016, workforce absorbed by this sector has contributed to Malang City economic for 12.9 percents which is higher than 12.5 percents in 2015. Growth rate of this sector in 2016 is 6.74 percents which shows an increase from 5.18 percents in 2015 .

\section{Wholesale \& Retail Trading of Car \& Motorcycle and Reparation:}

Jobs in this sector have successfully mediated production and consumption activities of goods and services. In 2016, it contributes to PDRB of Malang City for 29.53 percents, which indicates an increase compared to 28.89 percents in 2015. Sub-categories also play significant role, and they are Sub-Sector of Car \& Motorcycle Trade and Reparation and Sub-Sector of Wholesale \& Retail Trading of Non-Car \& Motorcycle which contribute to the jobs in this sector for 26.66 and 73.34 percents. General growth rate of this sector in 2016 has reached 6.84 percents. Meanwhile, both sub-sectors have growth rate of 4.30 and 7.82 percents.

\section{Education Service:}

This sector encompasses the educating activities in various levels of education and many education-related jobs, either those done in oral or written methods. Public and private educations provide educating activities such as sport, study tour, and education event. Although the contribution of education service to Malang City economic declines from 8.15 percents in 2015 to 8.13 percents in 2016 , such descending trend is negligible.

\section{Health and Social Activity Services:}

This sector embraces so many activities such as: Hospital Service; Health Clinic Service; Other HospitalBased Service; Physician Service; Healthcare by Paramedic; Traditional Health Service; Health Supporting Service; Special Transport for the Sick (Medical Evacuation); Animal Health Service; and Social Activity Service. In previous five years, the contribution of this sector to Malang City economic was increasing. In 2010, it contributed for 2.06 percents but increased to 2.49 percents in 2015 . However, growth rate of this sector declined in the last two years from 9.95 percents in 2015 to 8.27 percents in 2016 despite the fact that the contribution to Malang City economic climbs little from 2.49 percents in 2015 to 2.50 percents in 2016.

Taking into account the result of analysis on leading sector above, then it can be deduced that the most possible sector to be aimed for development is the Sector of Wholesale \& Retail Trading of Car \& Motorcycle and Reparation, especially its Sub-Sector of Wholesale \& Retail Trading of Non-Car \& Motorcycle.

Analysis on Leading Sector in Batu City:

Table 3: SLQ and DLQ of Batu City in 2012-2016

\begin{tabular}{|c|c|c|c|c|c|c|}
\hline Sector & Description & $\begin{array}{c}\text { SLQ } \\
\text { Means }\end{array}$ & Remark & $\begin{array}{l}\text { DLQ } \\
\text { Means }\end{array}$ & Remark & Conclusion \\
\hline $\mathrm{A}$ & Agriculture, Forestry and Fishery & 1.2639 & $>1$ & 0.9959 & $<1$ & Prospective \\
\hline $\mathrm{B}$ & Mining and Excavation & 0.0363 & $<1$ & 0.9577 & $<1$ & Laggard \\
\hline $\mathrm{C}$ & Processing Industry & 0.1512 & $<1$ & 0.9978 & $<1$ & Laggard \\
\hline $\mathrm{D}$ & Electric and Gas Supplies & 0.1524 & $<1$ & 1.0305 & $>1$ & Reliable \\
\hline $\mathrm{E}$ & $\begin{array}{c}\text { Water Supply, Trash \& Waste Management, } \\
\text { and Recycle }\end{array}$ & 1.9984 & $>1$ & 1.0040 & $>1$ & Excellent \\
\hline $\mathrm{F}$ & Construction & 1.1224 & $>1$ & 1.0360 & $>1$ & Excellent \\
\hline G & $\begin{array}{c}\text { Wholesale \& Retail Trading of Car \& } \\
\text { Motorcycle and Reparation }\end{array}$ & 1.0489 & $>1$ & 1.0071 & $>1$ & Excellent \\
\hline $\mathrm{H}$ & Transporation and Warehousing & 0.4643 & $<1$ & 1.0023 & $>1$ & Reliable \\
\hline I & $\begin{array}{l}\text { Accommodation and Food \& Beverage } \\
\text { Provisioning }\end{array}$ & 2.0130 & $>1$ & 1.0005 & $>1$ & Excellent \\
\hline $\mathrm{J}$ & Information and Communication & 1.3783 & $>1$ & 0.9899 & $<1$ & Prospective \\
\hline $\mathrm{K}$ & Finance and Insurance Services & 1.4677 & $>1$ & 0.9771 & $<1$ & Prospective \\
\hline $\mathrm{L}$ & Real Estate & 1.7133 & $>1$ & 0.9968 & $<1$ & Prospective \\
\hline $\mathrm{M}, \mathrm{N}$ & Company Service & 0.6409 & $<1$ & 0.9918 & $<1$ & Laggard \\
\hline $\mathrm{O}$ & $\begin{array}{c}\text { Government Administration, Defense and } \\
\text { Mandatory Social Service }\end{array}$ & 1.1301 & $>1$ & 0.9910 & $<1$ & Prospective \\
\hline $\mathrm{P}$ & $\begin{array}{c}\text { Education Service } \\
\end{array}$ & 1.4866 & $>1$ & 0.9898 & $<1$ & Prospective \\
\hline $\mathrm{Q}$ & Health and Social Activity Services & 1.2779 & $>1$ & 0.9872 & $<1$ & Prospective \\
\hline $\mathrm{R}, \mathrm{S}, \mathrm{T}, \mathrm{U}$ & Other Services & 11.3537 & $>1$ & 1.0065 & $>1$ & Excellent \\
\hline
\end{tabular}

Source: Data are processed.

Regarding to SLQ and DLQ means scores in above table, the leading sectors in Batu City can be explained as following:

\section{Water Supply, Trash \& Waste Management, and Recycle:}

Economic activities constituting this sector are related with water, such as collecting, processing, and distributing water through pipelines to fulfill water necessity of household and industry. Other activity is 
retaining, refining and processing water from many sources such as river, lake, spring, rain and others, but the usage is not for irrigating farmland. This sector contributes to Batu City economic for 0.17 percents in 2016 while its growth rate is 3.46 percents.

\section{Construction:}

Jobs provided by this sector had contributed to Batu City economic for 11.54 percents in 2014. It was higher than its contribution in 2015 which counted for 11.28 percents. Growth rate of this sector in 2016 is 8.90 percents, which is declining from 10.01 percents in 2015.

\section{Wholesale \& Retail Trading of Car \& Motorcycle and Reparation:}

Production and consumption activities of goods and services are successfully mediated in this sector. This sector contributes to PDRB of Batu City for 18.08 percents in 2016, which signifies an increase from 18.02 percents in 2015. Two sub-categories, namely Sub-Sector of Car \& Motorcycle Trade and Reparation and SubSector of Wholesale \& Retail Trading of Non-Car \& Motorcycle, are the dominant absorber of workforce in this sector with percentage point of 18.44 percents and 81.96 percents.

\section{Accommodation and Food \& Beverage Provisioning:}

Jobs in this sector has contributed to PDRB of Batu City for 12.06 percents in 2016 which is increasing from 11.64 percents in 2015. Sub-Sector of Accommodation Provisioning is the biggest contributor to the added-value of this sector. In 2016, the contribution of Sub-Sector of Accommodation Provisioning is 63.31 percents while Sub-Sector of Food \& Beverage Provisioning contributes for 36.69 percents. Growth rate of this sector in 2016 is 8.98 percents which declines from 9.62 percents in 2015.

\section{Other Services:}

This sector includes many services such as: Art, Entertainment and Recreation Services; Reparation of Computer, Personal Goods, and Household Appliances; Housekeeping Personal Service; Household Production of Goods and Service for Self-Interest; and Other Private Service. The contribution of this sector to Batu City economic in 2016 is 15.35 percents with growth rate of 6.92 percents. The role of this sector shall be significant due to the presence of Art, Entertainment and Recreation Services which are closely related with tourism. It is consistent with the standing of Batu City as Tourism City. Other sub-sectors have indeed great contribution to Batu City economic which is counted for above 15 percents. New tourist resort is always emerging every year, and therefore, growth rate of this sector in Batu City is always higher compared to other categories. In 2016, new tourist resort has been established in Junrejo District, namely Predator Fun Park, and it must provide new choice for tourists to visit Batu City at the weekend or during long holidays.

In regard to the result of analysis on leading sectors in Batu City, some sectors have the greatest opportunity to be developed. These sectors are:

1. Sector of Wholesale \& Retail Trading of Car \& Motorcycle and Reparation, especially for Sub-Sector of Wholesale \& Retail Trading of Non-Car \& Motorcycle.

2. Sector of Accommodation and Food \& Beverage Provisioning, especially for Sub-Sector of Accommodation Provisioning.

3. Sector of Other Services, especially for Sub-Sector of Art, Entertainment and Recreation Services.

Analysis on Leading Sector in Malang Regency:

Table 4: SLQ and DLQ of Malang Regency in 2012-2016

\begin{tabular}{|c|c|c|c|c|c|c|}
\hline Sector & Description & $\begin{array}{c}\text { SLQ } \\
\text { Means }\end{array}$ & Remark & $\begin{array}{c}\text { DLQ } \\
\text { Means }\end{array}$ & Remark & Conclusion \\
\hline $\mathrm{A}$ & Agriculture, Forestry and Fishery & 1.4294 & $>1$ & 1.0018 & $>1$ & Excellent \\
\hline $\mathrm{B}$ & Mining and Excavation & 0.4179 & $<1$ & 0.9566 & $<1$ & Laggard \\
\hline $\mathrm{C}$ & Processing Industry & 1.0073 & $>1$ & 1.0015 & $>1$ & Excellent \\
\hline $\mathrm{D}$ & Electric and Gas Supplies & 0.2837 & $<1$ & 1.0173 & $>1$ & Reliable \\
\hline $\mathrm{E}$ & $\begin{array}{c}\text { Water Supply, Trash \& Waste Management, } \\
\text { and Recycle }\end{array}$ & 1.0186 & $>1$ & 1.0078 & $>1$ & Excellent \\
\hline $\mathrm{F}$ & $\begin{array}{c}\text { Construction } \\
\end{array}$ & 1.2996 & $>1$ & 1.0026 & $>1$ & Excellent \\
\hline G & $\begin{array}{c}\text { Wholesale \& Retail Trading of Car \& } \\
\text { Motorcycle and Reparation }\end{array}$ & 1.0525 & $>1$ & 0.9949 & $<1$ & Prospective \\
\hline $\mathrm{H}$ & Transporation and Warehousing & 0.3758 & $<1$ & 1.0050 & $>1$ & Reliable \\
\hline I & $\begin{array}{l}\text { Accomodation and Consumption } \\
\text { Provisioning }\end{array}$ & 0.6432 & $<1$ & 0.9850 & $<1$ & Laggard \\
\hline $\mathrm{J}$ & Information and Communication & 0.8731 & $<1$ & 0.9983 & $<1$ & Laggard \\
\hline $\mathrm{K}$ & Finance and Insurance Services & 0.6293 & $<1$ & 0.9885 & $<1$ & Laggard \\
\hline $\mathrm{L}$ & Real Estate & 0.8359 & $<1$ & 0.9963 & $<1$ & Laggard \\
\hline $\mathrm{M}, \mathrm{N}$ & Company Service & 0.4737 & $<1$ & 1.0072 & $>1$ & Reliable \\
\hline $\mathrm{O}$ & $\begin{array}{c}\text { Government Administration, Defense and } \\
\text { Mandatory Social Service }\end{array}$ & 0.8144 & $<1$ & 0.9969 & $<1$ & Laggard \\
\hline
\end{tabular}




\begin{tabular}{|c|c|c|c|c|c|c|}
\hline $\mathrm{P}$ & Education Service & 0.9117 & $<1$ & 0.9996 & $<1$ & Laggard \\
\hline Q & Health and Social Activity Services & 0.8940 & $<1$ & 0.9978 & $<1$ & Laggard \\
\hline $\mathrm{R}, \mathrm{S}, \mathrm{T}, \mathrm{U}$ & Other Services & 1.5141 & $>1$ & 0.9967 & $<1$ & Prospective \\
\hline
\end{tabular}

After reviewing SLQ and DLQ means scores in above table, the leading sectors in Malang Regency are clarified as following:

\section{Agriculture, Forestry and Fishery:}

This sector concerns with many jobs related with agriculture, forestry and fishery. Various products are delivered by this sector, such as crops, horticultures, plantations, animal husbandry, farmland for hunting activity, forestland for wood logging, and fishes. Many jobs in this sector are becoming important structures to absorb workforces. The jobs are very potential, varying, and distributed throughout districts in Malang Regency. The outputs of Sub-Sector Agriculture such as crops, horticultures and plantations, have contributed to the sector for 87.90 percents in 2016. It put them in the first rank while the second is Sub-Sector of Fishery with contribution of 10.71 percents. The leading crops include rices, corns, cassavas, sweet potatoes, and beans, while plantations are often cultivated with sugar canes, coffees, cacaos, and coconuts. Horticulture commodities include potatoes, cabbages, peppers, and tomatoes. The commodities that constitute Malang Regency characteristic are apples, klengkeng, salak, oranges, and Kawi Mount cassavas. The performance of Sector of Agriculture, Forestry and Fishery is still limited because of problems challenging the Sub-Sector of Agriculture Crops, Animal Husbandry, Hunting, and Farming Service, and the Sub-Sector of Forestry and Wood Logging. Growth rate of Sector of Agriculture, Forestry and Fishery has reached 3.09 percents which it stands below fiveyear means of 4.03 percents. The performance of Sub-Sector of Crops grows slowly which leads to the laggardness in Sub-Sector of Agriculture. The declining performance of this sector is possibly influenced by La Nina Phenomenon which may decrease agriculture production, either crops or plantations. Similar declining trend also happens in Sub-Sector of Fishery which grows slowly at rate of 6.10 percents because of the decrease in fish haul rate and also in cultivated fishery production. In 2016, Sector of Agriculture, Forestry and Fishery has contributed to PDRB of Malang Regency for 17.52 percents based on current price. Sub-Sector of Agriculture Crops, Animal Husbandry, Hunting, and Farming Service is the biggest contributor with 87.79 percents. The next rank is occupied by Sub-Sector of Fishery with 10.85 percents and then followed by SubSector of Forestry with only 1.36 percents. Both Sub-Sectors of Agriculture and Fishery are performed well and thus it has positive growth. Most sub-sectors grow slowly if compared to previous period, and even Sub-Sector of Forestry grows in negative way. In reality, Agriculture is the main supporter of Sector of Agriculture, Forestry and Fishery, and it has growth rate of 3,09 percents, which is slower than previous year counted for 3.44 percents.

\section{Processing Industry:}

This sector plays important role in Malang Regency economic. The contribution of this sector to PDRB remains in the first rank. If reviewed from its contribution to export, the contribution of this sector is greater than Sector of Agriculture, Forestry and Fishery. Based on its contribution to workforce, this sector absorbs 16 percents of workforce total. The enterprises in processing industry have greater backward and forward linkage, and therefore, the increasing performance within processing industry has an impact on the other industry. Regarding to the role in economic, the performance of processing industry shows a positive growth trend in 2016. During the period of 2016, the growth rate reaches 6.00 percents and it is very high compared to the previous. The performance of processing industry is still above the average of other sectors in Malang Regency. Reason behind this high performance is the increasing order at some industries, such as clove processing industry and food \& beverage industry, because there is an increase in demands, sport activities, and culture events. Such increasing trend has brought a positive performance. Two sub-sectors are then giving the biggest contribution, and they are Sub-Sector of Clove Processing Industry with contribution rate of 46.61 percents, and Sub-Sector of Food \& Beverage Industry with 32.53 percents. The next rank is occupied by the Sub-Sector of Rubber, Rubber \& Plastic-Based Products, and the Equivalents with contribution rate of 3.61 percents, and followed by the Sub-Sector of Wood, Wood and Cork-Based Products, Bamboo and Rattan-Plaited Products, and the Equivalents with contribution rate of 3.50 percents. Other sub-sectors have contribution rate below three percents.

\section{Water Supply, Trash \& Waste Management, and Recycle:}

This sector is dominanted by economic activities related with water, such as collecting, processing, and distributing water through pipelines to meet water necessity of household and industry, and also retaining, refining and processing water from many sources such as river, lake, spring, rain and others. It must be noted that these activities are not for farmland irrigation. This sector contributes to Malang Regency economic only for 0.10 percents while the growth rate is 4.94 percents. It is slower than growth rate in 2015 which reaches 5.72 
percents.

\section{Construction:}

Construction Sector is the most affected sector from the policy of fossil-fuel subsidy reduction, especially when subsidied fossil-fuel price is set to increase. Jobs in this sector have been growing rapidly on second semester in 2016. This trend is triggered by the high number of ready-to-run infrastructure projects. As a result, the growth rate of jobs in this sector is 5.13 percents in 2016, and it is faster than previous year rated at 3.84 percents. In 2016, jobs in construction sector contributes to total economic of Malang Regency for 12.83 percents. The development of the last five years showed an increasing trend from 12.03 percents in 2012 to 12.83 percents in 2016.

Pursuant to the result of analysis above, some sectors are then possible to be developed, and these are:

1. Sector of Agriculture, Forestry and Fishery, especially for Sub-Sector of Crops, Plantations and Horticultures.

2. Sector of Processing Industry, especially for Sub-Sector of Clove Processing Industry and Sub-Sector of Food \& Beverage Industry.

\section{Analysis on Leading Commodity:}

Analysis on Leading Commodity in Malang City:

As previously shown in the analysis on leading sector, the leading sector in Malang City is Sector of Wholesale \& Retail Trading of Car \& Motorcycle Reparation, especially Sub-Sector of Wholesale \& Retail Trading of Non-Car \& Motorcycle. In general, trading itself has given Malang City a position as regional trade center. Trading activity in Malang City is divided into groups, such as:

1. Trading of vegetables, fishes and equivalents (wet market).

2. Trading at big scale (wholesale).

3. Trading of mixtures (garment, electronic and others).

Each district in Malang City has its own leading commodity on trade, and it can be elaborated as following:

a. Klojen District: Trading of mixtures (garment, electronic and others).

b. Blimbing District: Trading at big scale (wholesale).

c. Kedungkandang District: Trading of vegetables, fishes and equivalents (wet market).

d. Lowokwaru District: Trading at big scale (wholesale).

e. Sukun District: Trading of vegetables, fishes and equivalents (wet market).

\section{Analysis on Leading Commodity in Batu City:}

In regard to the result of analysis on leading sector, some sectors have excellent performance and they become the leading sectors. These are:

1. Sector of Wholesale \& Retail Trading of Car \& Motorcycle and Reparation, especially for Sub-Sector of Wholesale \& Retail Trading of Non-Car \& Motorcycle.

2. Sector of Accommodation and Food \& Beverage Provisioning, especially for Sub-Sector of Accommodation Provisioning.

4. Sector of Other Services, especially for Sub-Sector of Art, Entertainment and Recreation Services.

Jobs at Sector of Wholesale \& Retail Trading of Car \& Motorcycle and Reparation have successfully mediated the activities of production and consumption of goods and services. General trading in Batu City is divided into three groups, such as:

a. Batu District: Trading at big scale (wholesale).

b. Bumiaji District: Trading of vegetables, fishes and equivalents (wet market).

c. Junrejo District: Trading of mixtures (garment, electronic and others).

Sector of Accommodation and Food \& Beverage Provisioning, especially for Sub-Sector of Accommodation Provisioning, has given significant contribution to Batu City. This sector is represented by:

1. Star Hotel

2. Jasmine Hotel

Leading commodity in Sector of Accommodation and Food \& Beverage Provisioning in each district of

Batu City can be described as following:

a. Batu District: Star Hotel.

b. Bumiaji District: Jasmine Hotel.

c. Junrejo District: Jasmine Hotel.

Sector of Other Services, especially for Sub-Sector of Art, Entertainment and Recreation Services, is significantly giving high contribution to Batu City. Jobs in this sector are explained as following:

1. Natural Tourism

2. Artificial Tourism

Related to Sector of Other Services, leading commodity of each district in Batu City can be elaborated as 
following:

a. Batu District: Artificial Tourism.

b. Bumiaji District: Natural Tourism.

c. Junrejo District: Natural Tourism.

\section{Analysis on Leading Commodity in Malang Regency:}

There are two sectors in Malang Regency that occupies the leading poosition, and these are:

1. Sector of Agriculture, Forestry and Fishery, especially for Sub-Sector of Crops, Plantations and Horticultures.

2. Sector of Processing Industry, especially for Sub-Sector of Clove Processing Industry and Sub-Sector of Food \& Beverage Industry.

Sector of Agriculture, Forestry and Fishery gives significant contribution to Malang Regency economic. The most important activity in this sector is concentrated on Sub-Sector of Crops, Plantations and Horticultures. The outputs of this Sub-Sector include:

1. Rice

2. Corn

3. Cassava

4. Sweet Potato

5. Ground Bean (Peanut)

6. Green Bean

7. Soy Bean

8. Sugar Cane

9. Coconut

These outputs become the leading commodity in several districts of Malang Regency, and it can be described as following:

1. Donomulyo District: Sugar Cane

2. Kalipare District: Cassava

3. Pagak District: Sugar Cane

4. Bantur District: Sugar Cane

5. Gedangan District: Coconut

6. Sumbermanjing District: Rice

7. Dampit District: Rice

8. Tirtoyudo District: Cassava

10. Ampelgading District: Cassava

11. Poncokusumo District: Corn

Sector of Processing Industry, especially for Sub-Sector of Clove Processing Industry and Sub-Sector of Food \& Beverage Industry, also has delivered some leading commodities, such as:

1. Wood

2. Plait/Earthenware/Ceramic

3. Metal

4. Food

5. Leather

6. Woven Cloth

7. Others

The distribution of these leading commodities in the districts of Malang Regency can be elaborated as following:

1. Donomulyo District: Food Industry

2. Kalipare District: Wood Industry

3. Pagak District: Metal Industry

4. Bantur District: Plait/Earthenware/Ceramic Industry

5. Gedangan District: Plait/Earthenware/Ceramic Industry

6. Sumbermanjing District: Food Industry

7. Dampit District: Plait/Earthenware/Ceramic Industry

8. Tirtoyudo District: Plait/Earthenware/Ceramic Industry

9. Ampelgading District: Food Industry

10. Poncokusumo District: Wood Industry

\section{SWOT Analysis:}

Based on the data derived from interview with MSME agents and also from questionnaire, then information about internal or external environments are obtained. From this information, SWOT matrix is arranged. This 
matrix comprises of factors identifying internal and external environments. These key factors are strengths, weaknesses, opportunities and threats. These factors are then evaluated within IFAS and EFAS matrices. These matrices can be used as input data to determine the alternatives of business development strategy.

The considered strategy to develop MSME in Great Malang is given on the cluster of SO Strategy (Strengths-Opportunities) because this cluster produces the highest value than others. Therefore, it can be said that the development of Business Cluster in Great Malang shall be the priority for local government.

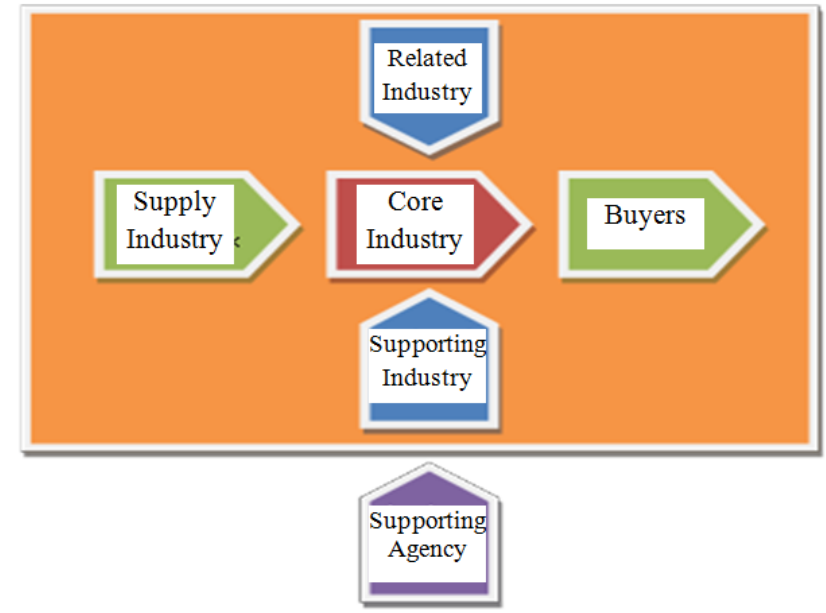

Fig. 3: Model of Development of MSME Business Cluster in Great Malang

SO Strategy (Strengths-Opportunities) is the selected strategy to development Business Cluster in MSME. This strategy is formulated based on analysis model in SWOT Matrix using data from EFAS and IFAS matrices. Result of SWOT Matrix has produced an alternative of strategy, and it is explained as following:

\section{Establishing Business Cluster:}

The establishment of business cluster is needed at least to ensure that the production and cooperation across business units would be feasible until their products enter the market.

\section{Opening Business Representative:}

Dealing with greater demand for MSME products from abroad market, then it is important to have higher

\section{Empowering Business Skill:}

In helping to initiate development in Great Malang regions, the innovative capacity of MSME entrepreneurs shall be built, and it can be done by utilizing work training house.

\section{Establishing Specialization:}

For creating commodities with better quality, some enterprises in same coverage may develop interaction, create better work environment, and disseminate works into work units.

\section{Reinforcing Capitalization:}

The good fate of MSME and their business activity can be ensured only through government support to develop MSME commodities. Large enterprises shall provide CSR fund to help MSME development.

\section{Designing Consult Program:}

Entrepreneurs can be helped to develop their business activity, and it is done by inviting them into consult program. This program would teach them about production technique, product design, marketing method, and enterprise management. The government may support the output of this program by giving entrepreneurs an access to higher quality commodities and by requiring large enterprises to allocate CSR fund to help MSME development.

\section{Conclusion:}

Malang City has some sectors with leading capacity, such as: (a) Sector of Water Supply, Trash \& Waste Management, and Recycle; (b) Sector of Construction; (c) Sector of Wholesale \& Retail Trading of Car \& Motorcycle and Reparation; (d) Sector of Education Service; and (e) Sector of Health and Social Activity Services. Batu City is supported with some leading sectors, which include: (a) Sector of Water Supply, Trash \& 
Waste Management, and Recycle; (b) Sector of Construction; (c) Sector of Wholesale \& Retail Trading of Car \& Motorcycle and Reparation; (d) Sector of Accommodation and Food \& Beverage Provisioning; and (e) Sector of Other Services. Several leading sectors in Malang Regency consist of: (a) Sector of Agriculture, Forestry and Fishery; (b) Sector of Processing Industry; (c) Sector of Water Supply, Trash \& Waste Management, and Recycle; and (d) Sector of Construction. Development strategy for MSME in Great Malang remains in the cluster of SO

Strategy (Strengths-Opportunities) because this cluster has given the highest value than others. It is concluded that the use of this strategy cluster shall be the priority of local governments in Great Malang for the development of business cluster in Great Malang.

\section{Implication of result of research:}

The implication taken from the result of research is that the governments of the cities and regencies in Great Malang shall collaborate with Department of Cooperative \& MSME, and also with Department of Industry and Trade, to support the development of MSME in Great Malang. Considering a fact that Great Malang economic has changed its orientation, precisely from the sectors orienting on agriculture to the sectors emphasizing on industry, trade and service, therefore the governments in Great Malang shall give more focuses on the lattest sectors when planning for local development.

To accelerate local development, local governments in Great Malang must improve the capacity of sectors in MSME. It can be done not only by giving emphasis on the outputs of agriculture sector but also improving agriculture technology to reduce import dependence in meeting the demand of agriculture sector.

\section{REFERENCES}

Astia, Dendi, 2004. Poverty Mitigation through MSME Empowerment: Some Lessions from Nusa Tenggara. Final Report of the Cooperation between Internal Affair Ministry, through its General Directorate of Local Development Fostering, and Deutsche Gesellschaft für Technische Zusammernabeit (GTZ) GmBH.

Blakely, J. Edward, 1998. Planning Local Economic Development: Theory and Practice, Sage Publications.

Bryman, A., 1988. Quantity and Quality in Social Research, Unwin Hyman, London.

Gunarianto and M. Nasri, 2011. Review on the Compilation of Competence of Local Industries in Pasuruan City. Result of Research.

Gunarianto, 2016. Capital Structure And Related Problems At Financial Firms That List With Indonesia Stock Exchange. Australian Journal of Basic and Applied Sciences, 10(9): 30-38.

Gunarianto, 2016. Effect of Good Corporate Governance, Motivated Behavior, Implementation of Accounting Information System and Real Earnings Management Behavior On Company Performance (Study at Go Public Manufacturing Co mpanies in Indonesian Stock Exchange). Australian Journal of Basic and Applied Sciences, 10(15): 92-101.

Gunarianto, A.T. Marjani and P.S. Endah, 2014. The Analysis of Earning Management and Earning Response Coefficient: Empirical Evidence From Manufacturing Companies Listed In Indonesian Stock Exchange. International Journal of Business and Management Invention, 3(8).

Gunarianto, A.T. Marjani and P.S. Endah, 2015. Effect of Good Corporate Governance, Motivated Behavior and Implementation of Accounting Information System on Real Behavior of Earnings Management (Study at Go Public Manufacturing Companies in Indonesian Stock Exchange). Australian Journal of Basic and Applied Sciences, 9(33): 337-345.

Gunarianto, Siti Asiyah and Alfiana, 2008. Review on Capital Investment into Sector of Trade and Service of MSME in Blitar City. Faculty of Economic, Malang Widyagama University. Result of joint research in cooperation with the Government of Blitar City.

Gunarianto, Tuti Hastuti and Siti Asiyah, 2007. The Formulation of Policy Concept to Improve Quality of Micro \& Small Industry Centers in Blitar City. Faculty of Economic, Malang Widyagama University. Result of joint research in cooperation with the Government of Blitar City.

Gunarianto, Tuti Hastuti and Siti Asiyah, 2008. Review on Allocation Strategy of the 2008 APBD to Accelerate IPM Improvement and Poverty Mitigation in Belu Atambua Regency. Faculty of Economic, Malang Widyagama University. Result of joint research in cooperation with the Government of Atambua City.

Helmsing. A.H.J., 2001. Local economic development: new generations of actors, policies and instruments. Draft paper for the 2001 Cape Town Symposium.

KRI International Corp, 2004. Final Report of Study about the Capacity Building of MSE Clusters in Indonesia Republic. The Government of Indonesia Republic through the Coordinator Ministry for Economic Issue, delegating to Department of Industry and Trade, and also through the State Ministry for Cooperative and Small \& Medium Enterprises, in cooperation with Japan International Cooperation Agency. Final Report is given on March 2004.

Maliza and Feser, 1999. Understanding Local Economic Development, Center for Urban Policy Research, 
New Jersey.

Module of Participatory Local Social Development (PLSD) in Planner Version, PSKM-UNHAS-JICA Indonesia, 1-10 August 2005.

Mulyono, 2015. The Design of Competitive Fostering Model for MSME in Mojokerto City. Result of Research.

Mulyono, 2016. The Making of Finance Skimming Policy for Primary Industry Sector in MSME in East Java. Result of Research.

Neuman, W.L., 2009. Social Research Methods, Qualitative and Quantitative Approach, Ally and Bacon, Bosto Gesellschaft für Technische Zusammernabeit (GTZ). Local Economic Development. Position Paper (Draft 2004): What Makes LED?

Sumodiningrat, 2004. The Setting of Poverty Mitigation Strategy. Article is presented at the Workshop of Experience Sharing across the Locals in their Poverty Mitigation Effort. It is held at Sanur Paradise Plaza Hotel, Denpasar, Bali on 2-4 July 2004. In cooperation with National Agency for Planning, World Bank, GTZ and DFID.

Tuti Hastuti, Alfiana and Siti Asiyah, 2013. Micro, Small and Medium Enterprise (MSME) Empowerment Model as the Effort for Poverty Eradication in Great Malang.. Result of Competitive Bequest Research (PHB). DP2M-DIKTI.

Tuti Hastuti, Alfiana and Siti Asiyah, 2014. Micro, Small and Medium Enterprise (MSME) Empowerment Model as the Effort for Poverty Eradication in Great Malang. International Journal of Business and Management Invention (IJBMI) Vol.3 - Issues 1 (January-2014 Version). Result of Competitive Bequest Research (PHB) on First Year.

Tuti Hastuti, Alfiana and Siti Asiyah, 2015. Micro, Small and Medium Enterprise (MSME) Empowerment Model as the Effort for Poverty Eradication in Great Malang. International Journal of Business and Management Invention (IJBMI) Vol.3 - Issues 1 (January-2015 Version). Result of Competitive Bequest Research (PHB) on Second Year. 